\title{
Tuberculosis Treatment by Laser
}

\author{
Victor V Apollonov* \\ GPI RAS, Russia \\ *Corresponding author: Victor V Apollonov, GPI RAS, Vavilov str 38, Moscow, Russia
}

\begin{tabular}{|c|c|}
\hline ARTICLE INFO & ABSTRACT \\
\hline Received: 閏July 25, 2019 & Citation: Victor V Apollonov. Tuberculosis Treatment by Laser. Biomed J Sci \& Tech Res \\
\hline Published: August 01, 2019 & 20(2)-2019. BJSTR. MS.ID.003417. \\
\hline
\end{tabular}

\section{Short Communication}

Treatment of patients suffering from fibrous-cavernous tuberculosis of lungs is still one of the most difficult and vital problems of modern medicine. The urgency of this problem is associated with the fact that the number of people infected with pulmonary tuberculosis is rather high and amounts to 30-70 per 100000 people. These are the average data. In some regions, this rate exceeds 200-250 per 100000 of population (e.g., in India). According to the data of the International Health Organization, from two to three million people die of pulmonary tuberculosis every year, whereas the total number of infected cases reaches 50-60 million. Modern chemotherapy is quite promising in the treatment of patients with the first onset pulmonary tuberculosis. However, the conservative treatment appears to be inefficient for the treatment of $20-30 \%$ of patients with complications of the tuberculosis process, because of the development of irreversible changes. In addition, ecological problems increase the probability of allergic reactions to chemo preparations.

After a long-term treatment, the develops a habituation to drugs, which may cause damage to some other internal organs in the course of treatment of tuberculosis. Note that during the last decade, not a single new drug appeared for the treatment of pulmonary tuberculosis. The aforesaid led to the development of a method for a local action on a tuberculosis cavern accompanied by such a physical treating factor as ultraviolet laser radiation, possessing a pronounced bactericidal action. The method is based on new approaches and the solution of physical, technical, and medical problems. The ultra-violet laser system "AMULET" for the treatment of chronic cavitating lung tuberculosis has been created in HPL Dept. of GPI RAS \& JSC “Energomashtechnika” in cooperation with Scientific Research Institute of Phtisiopulmonology of Moscow Medical Academy after I.M.Sechenov and in accordance with the
"Moscow Science and Technology Committee"(director at that time- L.L.Semenov) grant.

The "AMULET" based on all-solid-state diode pumped Q-switched YVO4: Nd-laser. This laser system provides high-energy pulses and high repetition rates in a compact air-cooled package. Available in fundamental (1064 nm.), frequency-doubled (532 nm) or frequency-quadruped (266 nm) allow the "AMULET" to replace many laser system as well as possibility to modernization for another wavelength $(1320 ; 660 ; 355 \mathrm{~nm})$.

Furthermore, the laser system "AMULET" has compact size, high efficiency and convenience of use. The UV medical system "AMULET" consists of laser head, power supply and control system of acousto-optic modulator. Power supply designed specifically for the safe and fault-free operation of laser diodes, it includes a diode protective circuits, a feedback photodiode circuits, overcurrent limit, and full TE cooler control. The driver provides digital display of four key operating functions. Microprocessor 180C516B serves as a central control unit of the driver. This allow to work with very broad range of laser diodes, termocoolers, termoresistors and feedback photodiodes. Acousto-optical modulator is driven by RF $5 \mathrm{~W}$ generator at central frequency $80 \mathrm{MHz}$.

Laser head consist of diode laser pumping system, acousto-optic Q-switched longitudinally pumped laser system of frequency-doubling and frequency-quadrupling and system of fiber-guide output power. A. M. Prokhorov General Physics Institute of the USSR Academy of Sciences (GPI) was founded on September 30, 1982, on the basis of the Division "A" of the P. Lebedev Physical Institute of Russian Academy of Sciences (FIAN). At the present GPI is a multi-profile institute engaged in the general physics research, mainly in the areas of quantum electronics and optics, solid-state 
physics and surface physics, micro-electronics, integrated optics and fiber-optic communications, plasma physics and hydro-physics, and physics of magnetic phenomena.

The founder of the Institute was Alexander M. Prokhorov, a world-known scientist, winner of Lenin, State and Nobel Prizes. High Power Lasers Department is a leader in development of advanced high-power lasers. It is the division of the General Physics Institute of the Russian Academy of Science. Extensive scientific research and development of various types of lasers and laser technology has earned a lot of respect among scientific community all over the world. On the basis of the Department, JSC" Energomashtechnika "was established in 1993 under personal support of acad. A. M. Prokhorov. It has soon earned reputation of an active, reliable, high-effective company acting at domestic and international markets of modern high-power laser technologies. JSC "Energomashtechnika "offers a wide range of advanced laser products, technologies and services. Intensive and elaborate research in the field of high-power lasers has made the technologies developed by the company the most unique and progressive among others. Numerous patents and contracts with foreign and domestic customers are a prove of this fact.

The President of the company and "High Power Lasers "Department chief, Victor V. Apollonov, Prof. of Physics, is an author of more than 550 patents and publications in scientific periodicals. He is the Winner of USSR (82) and Russia (01) State Prizes, Academician of RANS. Research associates of the Department are highly skilled specialists and many of them have academic degrees. Wide spectrum of HPL Dept. of GPI RAS \& JSC "Energomashtechnika" activities is presented in particular in the Proceedings of International conference on "Lasers" since 1985 and up to now (see our website: www.gpi.ru/hpl).Among of research areas is being now developed in "High Power Laser "Dept. of A. ProkhorovGPI RAS:

a) Diode pumping of solid-state lasers.

b) Nonlinear conversion.

ISSN: 2574-1241

DOI: $10.26717 /$ BJSTR.2019.20.003417

Victor V Apollonov. Biomed J Sci \& Tech Res

This work is licensed under Creative

Commons Attribution 4.0 License

Submission Link: https://biomedres.us/submit-manuscript.php c) Medical UV diode pumped solid state lasers.

The former Director of Scientific Research Institute of Phtisiopulmonology of Moscow Medical Academy after I.M. Sechenov Acad. M. I. Perelman was the scientific leader of medical part of research. The scientists of the Institute have made a substantial contribution to the development of antituberculosis vaccination, chemoprophylaxis, chemotherapy, surgical treatment of tuberculosis. Fundamental research has been carried out in the field of pathogenesis, pathomorphism, immunomorphology and histochemistry of tuberculosis, biochemistry and pathophysiology, experimental and clinical immunology of tuberculosis, bacteriology of tuberculosis: latent microbism, structural and biological properties of the tuberculosis agent.A new methods are being developed and previously applied methods are being improved for the surgical treatment of patients with fibrocavernous tuberculosis and chronic non-specific lung and pleural diseases using ultrasound and different types of lasers developed in HPL Dept. of AM Prokhorov General Physics Institute (Figure1).

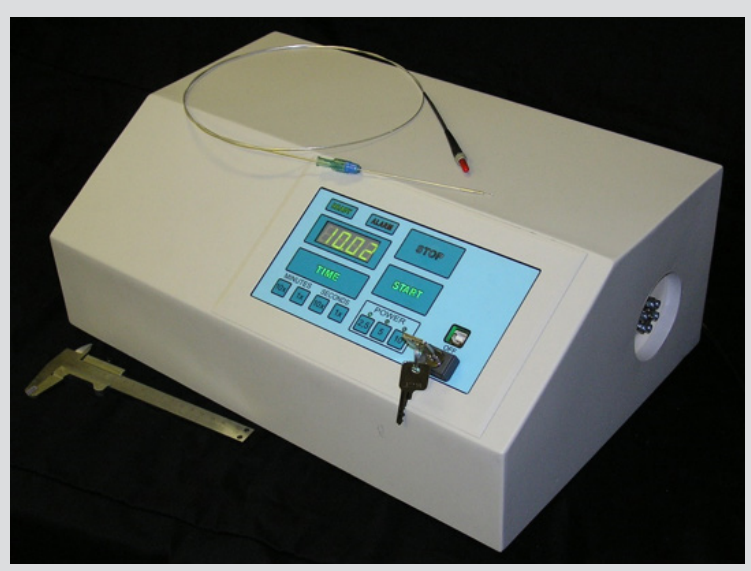

Figure 1.

\section{Conflict of Interest}

No conflict of interest.

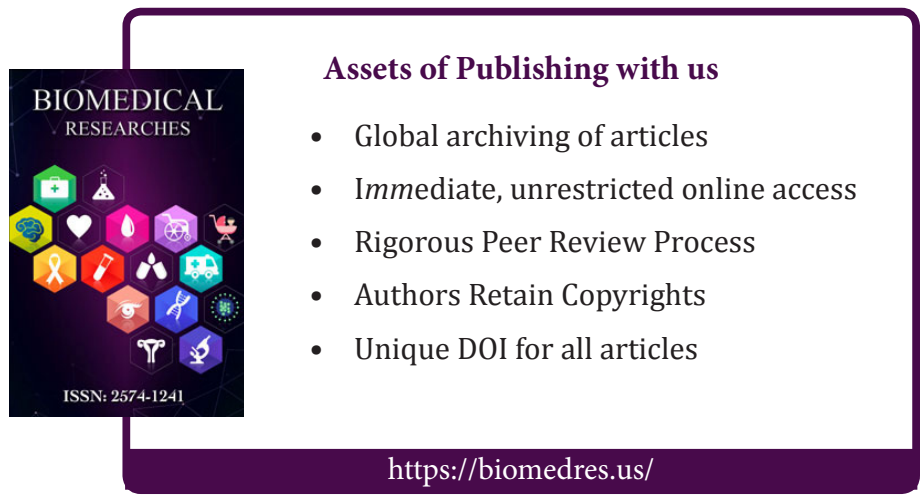

Copyright@ Victor V Apollonov | Biomed J Sci \& Tech Res | BJSTR. MS.ID.003417. 